\title{
Information Community as Natural the Phase of the Historical Development of World Civilization
}

\author{
Vladimir Sergeevich Grodsky* \\ Samara State Polytechnic University, Russia \\ *Corresponding author: Vladimir Sergeevich Grodsky, Samara State Polytechnic University, Russia
}

\begin{abstract}
ARTICLE INFO
Received: 慧 January 16, 2021

Published: 幽 January 22, 2021

Citation: Vladimir Sergeevich Grodsky. Information Community as Natural the Phase of the Historical Development of World Civilization. Biomed J Sci \& Tech Res 33(2)-2021. BJSTR. MS.ID.005384.

ABSTRACT

The economy of a post-industrial society is interpreted as the unity of information technologies and global production institutions. The methodological and instrumental specificity of the study of the economy, which is an open non-equilibrium self-organizing system, is shown. One of the latest trends in science is considered - economic kinetics, or meta-economics, which studies the laws of the evolution of world civilization. The article presents a critical analysis of the existing theoretical approaches to identifying historical types of economic management, demonstrates a new model of economic formations and interformational transitions, justifies the introduction of a new production criterion in the digital economy - labor wages, which ensures the predominant development of human capital.
\end{abstract}

Keywords: Digital Economy; Production Technology; "Sociology" of Production; "MetaEco-Mix"; Economic Formation; Profitability of Capital; "Wages" of Labor

\section{Introduction}

The expression "digital economy" is a metaphor that characterizes a certain quality of post-industrial society, or rather a system of information production technologies and institutions adequate to them. Information technology is a reality unfolding before our eyes on a global scale. As for institutions, scientists in general, and especially social scientists, have a little work to do. to create new rules and institutions necessary for the full functioning of the existing and expected information technologies in the future. A significant role in this matter should also belong to economic theory (economics), which has succeeded in studying the functioning of the modern market economy but is still unable to satisfactorily describe both the historical past and the long-term future of social production.

American economist Paul Samuelson (1915-2009), author of the famous textbook Economics: an introduction to analysis (1948), in the Conclusion of the slightly earlier published Foundations of Economic Analysis (1947) noted that from the point of view of the "mainstream of economic science" [ Samuelson, p. X], "analytical economic theory" [Samuelson, p. XV], there are six stages of its development: 1) research of static equilibrium of the economy; 2) achieving comparative economic statics; 3 ) the theory of maximizing behavior of an economic entity; 4) introduction into the scientific circulation of the "principle of correspondence" of comparative statics and dynamics; 5) the theory of economic dynamics; 6) the theory of "comparative economic dynamics" [Samuelson, p. 355] [1].

According to the author, at the sixth stage of the development of the theory, "it should include ... all the five subjects considered above, but at the same time it should cover a wider "territory" [Ibid.]. This stage, which can be conditionally called "economic kinetics", is not "Economic history", but the science of the laws of development of human civilization, it is the science of interrelated nonequilibrium processes of self-organization in society, using the tools of synergetics. It is the relatively new economic synergy that will allow us to satisfactorily describe the trend of economic development and those institutional innovations that are necessary for the current economic practice. This article does not set the task of a comprehensive characterization of the "digital economy" and the institutions of the information community, but an attempt is made to retrospectively analyze the historical development of social production and create a new model of its formational division, which, in our opinion, will facilitate the solution of development tasks. necessary specific institutional transformations. 


\section{Accumulated Achievements of the Theory of Economic Development}

Due to the multifactorial nature and complexity of the process of the progressive evolution of the economy, the impression of complete arbitrariness in its directions and forms is created. However, for all the "elasticity" and stochasticity of the course of development of society, it is still subject to the action of objective laws, the knowledge of which gives more accurate knowledge about the past, the present and future of human civilization, that is, it reveals its historical trend. Therefore, the science of economics in the broad sense of the word, instead of scanty and amorphous "Introduction to the market economy", needs a de-ideologized and advanced section "Meta-economics", which would contain modern models of historical forms of economic management and the nonequilibrium theory of interformational transitions. Scientific research of a meta-economic nature has a long history. In economic theory, sociology, history and science in general, there is a large number of theories of structuring the process of the development of human civilization, which traditionally belonged to the so-called "philosophy of history" [2].

Although the term "philosophy of history" appeared only in Voltaire (François Arouet) (1694-1778) (Philosophy of History, 1769), practically the corresponding subject was discussed from ancient times and arose from the works of the ancient Greek narrators Herodotus (484-425 BC) (History) and Thucydides (460396 BC) (History). A certain philosophy of history was contained in the Bible and was most clearly presented in the City of God (413427 ) by the Catholic theologian Aurelius Augustine (Blessed) (354430). He considered history to be a process of separating the evil of the earthly city from the good of the heavenly city, which should end with a "terrible judgment" and consists of six periods: from the creation of the world to the flood, from Noah to Abraham, David, before the Babylonian captivity, before the birth of Christ and before his second coming.

The ideas of the periodicity of the development and improvement of Augustine's society found a continuation in the work of the Italian monk Io-chim of Flora (Gioacchino da Fiore) (1132-1202) (Coordination of the Old and New Testaments; Commentaries on the Book of Revelations), who suggested considering three eras instead of the one adopted in at that time of dividing chronology into two parts, he considered the historical triad corresponding to the "trinity": the "age of the Father" of the Old Testament period, the "age of the Son" of the New Testament period, accounting for 42 generations of 30 years each, Spirit ", which was supposed to begin according to Floorsky's calculations in 1260. The millennial "age of the Spirit", according to the author, should not know private property, slavery, poverty and war. Thus, in Floorsky we find a second theological periodization of the history of the development of mankind and a characteristic of high promising socio-economic norms. For all the primitiveness and theological nature of both structures, they are distinguished by their expansive content, including, in addition to the history itself, natural and predictive elements, and are preserved for a long time in the ideas of ordinary people and scientists [3].

Only by the middle of the 18th century did materialistic ideas about the division of history appear. The most famous were the concepts of French scientists, in particular the concept of SaintSimon (Henri de Rouvroix) (1760-1825) (On the industrial system, 1821), according to which the stages of history are determined by the form of organization of labor and are built in primitive cooperation, slavery, serfdom, the "industrial system" of wage labor and a society without exploitation, and the concept of "changing ways" by Jacques Turgot (1727-1781), presented in his Discourses on General History (1750), where he singled out hunting-gatherer, shepherd, agricultural life support and commercial and industrial society. Partly, the representations of Saint-Simon formed the basis of the anti-Marxist concept of the "industrial society" of his compatriot Jean Fourastier (1907-1990) (Great Hope of the XX century, 1949) with the sequence: agricultural (primary), industrial (secondary), service (tertiary) and spiritually creative (quaternary) "civilizations". American Walt Rostow (1916-2003) (Stages of Economic Growth, 1960) he absolutized the industry in his theory of "stages of growth", approached history onesidedly, put the level of development of machine technology in the first place. They distinguished two main types of production - "traditional" and "industrial". The other three stages of growth (the stage of "preparing the conditions for a shift", "transition to industrial development" and "mass consumption") characterized the processes of transition from a traditional society to an industrial one [4].

Modern authors of various concepts of the division of history base it on various forces and signs of nature and society. So, for example, the Soviet biophysicist Alexander Chizhevsky (1897-1964) (Physical factors of the historical process, 1924) saw the cycles of activity of the Sun as the reason for the diversity in the development of society, which, in principle, fits into the classical natural social $\neg$ ny continuum ". The Russian American sociologist Pitirim Sorokin (1889-1968) (Social and Cultural Dynamics, 1937-1941) proposed to single out the "supersystems" in history on the basis of different "types of worldview". But this approach to the structure of history seems superficial and one-sided. The English theorist Arnold Toynbee (1889-1975), in his extensive twelve-volume study of History (1934-1961), considered the general historical process as the development of thirteen main closed (not counting minor and undeveloped) civilizations. But important for the confirmation of the considered formational theory of the German thinker Karl Marx (1818-1883) [Marx, 1867] from Toynbee's ideas is, in our opinion, only the historical details of his "civilizations", each of which goes through the stages of emergence, growth, breakdown and decay, after which it perishes, giving way to another. 
In general, Western economic thought rarely addressed the question of structuring the history of society, either without considering it important, or too complicated, or not recognizing the natural character of the development of social production. Thus, the Austrian researchers, economists Ludwig von Mises (1881-1973) (Theory and history. Interpretation of socio-economic evolution, 1957) and Friedrich von Hayek (1899-1992)

(Social Sciences Facts, 1942), as well as the philosopher Karl Popper (1902-1994) (Poverty of Historicism, 1957), influenced by the anti-historicism of the French philosopher Raymond Aron (1905-1983) (Introduction to the Philosophy of History, 1938), affirmed: "There is no prime mover of the entire historical movement" [5]. Only in the most recent time has it been marked by a certain strengthening of historical problems in economic theory, stimulated, on the one hand, by the successes of institutionalism, and, on the other hand, by the practical need to explain and predict qualitative transformations in modern society. Marx's theory and the Marxist trend in the development of economic theory turned out to be very fruitful in the issue of identifying qualitatively definite, replacing historical forms of economy, since they were based on universal criteria for the growth of production efficiency and human freedom.

However, the incompleteness of Marx's formational model, its distorted interpretation, the general dogmatic approach to "political economy in a broad sense" in the theory of real socialism, and the subsequent rejection of the practice of "building communism" did not make it possible to create a true dialectical model of change historical forms of economy. At present, after a long period of the official canonized Marxist ideology and the subsequent collapse of the "socialist economic system" in Russia, the attitude to Marx's formational theory was emotionally negative and it was rejected. At the same time, the crisis of the industrial society, which broke out in the West, makes specialists again turn to Marx. After a strip of sharp criticism of Capital, the so-called neo-Ricardianism is formed - a trend in economics that continues Marxism and the theory of real socialism, there is a kind of "renaissance" of Marx's theory as a whole. The English economist Mark Blaug (1927-2011) wrote about this: "In his hypostasis of the economist, Marx ... is still relevant as none of the authors, ... his ideas have become an integral part of the world of ideas in which we all think" [Blaug, from. 207]. An ever-wider circle of scientists and politicians are constantly turning to the scientific legacy of Marx. The need to work out a longterm development strategy for Russia requires the rehabilitation of the formational teachings of Marx in the country.

\section{Required Formational Improvements}

\section{Karl Marx Models}

The ideas inherent in Marx's formational model, in our opinion, have not exhausted their heuristic potential, at present they attract the attention of economists, but they need certain development and improvement, supplemented with institutional elements.
It is also necessary to revise the system of generalized economic coordinates and indicators of Marx. The fair Marxist thesis that each historical stage in the development of economic activity has special production relations inherent only to it, not only does not exclude, but, on the contrary, presupposes the need to develop universal initial concepts and categories, the use of which makes it possible to trace the development of the natural social continuum, the continuity of the transition from the "economy of nature" to the "nature of the economy", designated by the classic of political economy, the Englishman Adam Smith (1723-1790) (Study on the nature and causes of the wealth of peoples, 1776) [6].

The fundamental characteristics of the economy correspond to its most stable, deep structure. The morphology (structure) of the economy in a generalized form was considered by the theorists of the period of classical political economy, the Frenchman Francois Quesnay (1694-1774), the Englishmen James Lauderdale (17591839) and Da-vide Ricardo (1772-1823). The greatest contribution to the solution of the issue of generalized structural indicators of the economy was made by Marx. Although Marx considered the most important definition of the type of society, the relations between its classes, property and the organization of labor, he did not exclude the possibility of studying the "production process in general", in the form "in which it is characteristic of all social structures, that is the process of production outside of its historical character, if you like, a common human process "[Marx, vol. 46, part I, p. 274].

The analysis of the "production process in general" indicates its duality, its existence as labor and human cooperation at the same time. "Production ... manifests itself as a natural (labor) ... [and] social relation, social in the sense that it means the cooperation of many individuals, it does not matter under what conditions, how and for what purpose" [Marx, vol. 3. p. 28]. "Labor is, first of all, a process that takes place between man and nature, a process in which man, by his own activity, mediates, regulates and controls the exchange of substances between himself and nature ..." (Marx, vol. 23, p. 188 ). But in production "people enter into relationships not only with nature. They cannot produce without uniting in a known way for joint activity and for mutual exchange of their activity "[Marx, vol. 6, p. 44]) [7].

Communication relations can be called "cooperation relations" in a general, essential sense. Historically, these relations can be far from cooperation and even opposite to it, for example, in market conditions they take the form of rivalry. And yet, historical, concrete modifications of industrial communication cannot completely suppress in it the initial and permanent cooperativeness, interdependence and assistance of producers. It is the social nature of production, as opposed to the individuality of labor, that is taken into account by the category of "relations of cooperation." The totality of "labor" and "cooperation" can be called "human activity". Production relations cannot exist and develop by themselves, in their pure form, they are always mediated, materialized. "Political economy deals not with things, but with relationships between 
people ..., but these relationships are always associated with things and are manifested as things" [Marx, vol. 13, p. 498]. Therefore, the interaction of people with the surrounding nature (production relations of labor) materializes in the means of labor, and the interaction of people with each other (production relations of cooperation) materializes in the means of communication, in social institutions, that is, in the "economic mechanism" in the broad sense of this concept, covering not only economic, but also all other institutions of society. If the instrumentalization of labor mediates the interaction of a person with an external object, then the institutionalization of cooperation orders, regulates and ensures the stability of human life [8].

The means of labor and cooperation are "means of production" in the broad sense of this concept and characterize the level of development of all production relations. In Marxist literature, a person is usually declared a "bearer of production relations," but in reality the means of production are the material substrate of relations. Man is the subject of production relations. The analysis of the duality of production relations and the means of their realization inevitably affects the concepts of "productive forces", "basis", "superstructure" and "socio-economic formation", considered in detail by Marx.

First of all, we note that when the concept of "basis" is expanded to include production relations of labor, the concept of "superstructure" is also transformed, since labor relations have their own "superstructure", their material design in the form of means of labor. We call these means of labor, in conjunction with the labor process itself, "production technology" and consider this concept as the first universal, generalized coordinate of meta-economics. This approach of Marx is most concentratedly expressed in the concept of "basis" as a set of relatively stable production relations of society, relations that represent its structure. However, the "superstructure" of society in this case, as we have already noted above, does not contain "basic" institutions. It turns out that the institutional design of production relations in Marx is outside the economy and society, and the corresponding concepts are outside the subject of economic theory.

In reality, however, the economic superstructure exists in the form of an "economic mechanism" as a material substrate, means of realizing production relations of cooperation, that is, a system of informal customs, principles, norms, rules that regulate and ensure sustainability, developed in the course of economic practice and its cognition. economic life of society. The economic mechanism organizationally formalizes the existing system of production relations of cooperation. Since material production is the main sphere of human life, the real relationship of interdependence that develops between people in the process of their work is the basis of other political, legal, religious, moral and other social relations. The Russian Marxist Vladimir Lenin (1870-1924), in our opinion, rightly noted that "we, structuring society, distinguish production relations from different areas of social relations as the main, initial, determining all other relations." [Lenin, vol. 1, p. 133, 134]. Therefore, the economic part of the "superstructure" is its main component, which determines all other social orders and formations [9].

This means that, for example, "the political system ... is only the official expression of civil society" [Marx, vol. 27, p. 402] that politics as a "concentrated expression of economics" [Lenin, vol. 42 , p. 278] "always only reflects, records the requirements of economic relations" [Marx, vol. 4, p. 112]. The economic essence can be found in other social institutions. You can even say that non-economic social institutions represent a kind of infrastructure of the economic mechanism. This infrastructure completes and fully realizes the structure of society. That is, the statement on the primacy of economics means that non-economic institutional formations are not so much derived from economic relations as necessary for their existence and reproduction. At the same time, one can speak of all existing institutions of society as an "expanded economic mechanism." From the momentary complex system of modern social institutions in the historical aspect, its various elements acted as an economic mechanism, the sequence of which was as follows - institutions of kinship, political, religious, market, and in the future, ethical institutions will act ... That is, the means of implementing production relations of cooperation were alternately taboos and customs, the state, the church, the establishment, and in the future self-government will also be used.

This circumstance allows, in general terms, the entire complex of social relations and institutions to be considered a single economic mechanism. In this broad sense, we call it the "sociology of production." We oppose this concept as the second generalized coordinate of economic theory to the coordinate "production technology". "Social relations are also produced by people, like canvas, linen, etc." [Marx, vol. 4, p. 133], as well as the institutions of society. Therefore, the sociology of production and production technology are integral systems, but also closely interrelated formations. Thus, the economic structure of society can be represented with the help of the dualism "technology-sociology of production", which can replace the triad "productive forces-basissuperstructure" of society and become a more productive tool for understanding the dialectics of economics. If the triad of Marx was traditionally considered the subject of the so-called "Historical materialism", then the proposed generalized coordinates should, in our opinion, be included in the subject of economic theory in its broadest understanding, which we called the metaekonomix [10]

Above, we gave a qualitative description of the technology and sociology of production, which are universal generalized coordinates of meta-economics that permeate the history of social production. But these coordinates require their own quantitative measures, which would make it possible to carry out a comparative (comparative) analysis of the historical forms of the economy, to 
investigate the laws of the development of society. In this aspect, economics cannot differ from the natural sciences, which have long had generalized indicators. The development of general historical economic indicators is a very difficult task, but it is necessary for the current stage of its development, characterized by the transition from the stage of analytical differentiation and accumulation of knowledge to the stage of its integration and synthesis. To introduce the required indicators for the coordinates "production technology" and "sociology of production", we will use Marx's methodology for measuring the levels of development of production relations, which introduced the indicators "organic structure of capital" and "rate of surplus value" into our analysis of the capitalist economy.

To give these indicators a general historical character, we express the structure of the aggregate product of society in the following form: $\mathrm{Q}=\mathrm{C}+\mathrm{V}+\mathrm{M}$, where $\mathrm{C}$ is the natural rent, which contains the overwhelming part of the material costs of production, $\mathrm{V}$ is the cost of living labor in monetary terms, and $\mathrm{M}$ - total profit in the form of the so-called "cash flow" (cach flow), which includes depreciation deductions and net profit. Let's call the ratio C / V "the level of development of production technology" (P), and the ratio $\mathrm{M}$ / V - the level of development of institutions of society, "sociology of production" (S). Both indicators historically as a whole increase, the first - as living labor is replaced by materialized, and the second - due to the increase in the economy in the amount of capital goods, their depreciation and net profit per unit of living labor.

We have shown above that labor is a production relation. However, the relationship of communication is a united "laborcooperation", "that is, an intelligent productive force that arises due to the joint activity of different individuals conditioned by the division of labor ..." [Marx, vol. 3, p. 33]. Profit is the emergent (systemic) effect of division and cooperation of labor. In other words, we can say that production technology creates the value of the product, and the sociology of production redistributes it in such a way that the profit of cooperation is formed. Technological economy is realized only through "political economy", since "combined activity means organization" [Marx, vol. 18. p. 303] [11]

As a consequence of the expansion of the exchange of substances between nature and society, in history there is a growth and improvement of the means of labor, which are becoming more and more adapted to a person, constituting an integral part of his workforce. But the development of the "technological body" of the subject of production is not the only result of strengthening the connection between society and nature. Man, "acting on external nature and changing it, at the same time changes his own nature. He develops the forces dormant in it and subordinates the play of these forces to his own power "[Marx, vol. 23, p. 188, 189]. The same can be said about the "sociological body" of a person: the development of institutionalized cooperation is impossible without the development of personality. Thus, in the general historical aspect, the harmony of the evolution of objective and subjective components of the productive forces is generally realized.
The proportional-disproportionate superwave development of human civilization in the coordinates "P - S", shown in Figure 1, corresponds to the theory of natural-social continuum (continuity) of Smith and the theory of discrete social development of Marx, since the model reflects the possibility of rapid technological progress only with a certain stability of the sociology of production and vice versa. In addition, the model synthesizes the concept of development of society with an impulse from Marx's technology with a concept of development with an impulse from the sociology of production by the German sociologist Max Weber (18641920) (Protestant Ethics and the Spirit of Capitalism, 1904). For a relatively developed economy, an alternate causal relationship between technologies and sociologies of production is obvious, while for the stage of the emergence of society and economic activity, the question of the root cause becomes important and fundamental. The explanation of the very fact of the periodicity of economic development, the understanding of the economic unity of the history of society, to which many theoretical economists aspired, the explanation of many complex historical phenomena of the economic life of society, as well as the quality long-term forecasting of changes in production [12].

"History can be viewed from two sides, it can be divided into the history of nature and the history of people. However, both of these sides are inextricably linked"[Marx, vol. 3, p. 16]. In anthropology, as a rule, "human consciousness" is taken as the fundamental factor of anthropogenesis. However, homo sapiens is derived from homo faber: "The first historical act ... of individuals, thanks to which they differ from animals, is not that they begin to think, but that they begin to produce the means of life they need" [ Marx, vol. 3, p. 19]; "Consciousness ... from the very beginning is a social product and remains so as long as people exist at all" [Marx, vol. 1, p. 478]. The well-known position of Engels that "labor created man" cannot be recognized as accurate, since the productivity of "labor" from "cooperation", the derivation of the primordial technology of production from its sociology, technogenesis from sociogenesis was shown. The "intellectual" interpretation of anthropogenesis, as well as Engels's labor theory of the origin of man, do not completely solve the problem, because they raise questions: "Why does an individual become a rational being and why does an individual begin to work, produce material goods?" Therefore, only the "ecological" concept of the emergence of society deserves attention.

Economic literature usually simply states the cooperativeness and instrumentality of the activity of ancient man, while in reality anthropogenesis not only requires some explanations from the economic theory, but also has an economic essence, which, in our opinion, can be cognized within the framework of meta-economics. First, anthropogenesis lends itself to explanation only from the standpoint of the natural-social continuum, and for this, first of all, it must be divided into two parts - socio-and technogenesis. The nature of the interaction between the natural environment and the proto-society is described by the universal "Le Chatelier 
principle" proposed by the French chemist Henri le Chatelier (1850-1936), according to which the effect that brings the system out of equilibrium is, causes processes in it that seek to weaken this impact. A sharp deterioration of the habitat associated with coldness due to the onset of the next geological ice age on the planet about a million years ago, caused such an internal restructuring in the proto-society, which to a significant extent compensated for the external catastrophic unfavorable ecological gical impact. The change in the internal structure of the system in this case could be reduced only to a closer contact of individuals, to their cooperation. The break of subjects with a familiar object - a nature useful for them - meant the establishment of additional intersubjective relationships [13].

This cooperation of individuals has conditioned the formation of the primordial "sociology of life" in the form of a set of certain rules, norms, taboos (prohibitions), traditions, language, and the mythological consciousness of people. Thus, sociogenesis is primary in history. In Figure 1 shows a socio-technological cycle with an initial deviation towards "sociology", S. It is important to keep in mind that this beginning of history determines the entire subsequent cyclical evolution of society and the economy. The trend equation of economic development $\mathrm{S}=\mathrm{P}$ in the second approximation of our model to reality, taking into account the frequency of movement of society, can be written in the following form: $\mathrm{S}=\mathrm{P}+\mathrm{e}$ sins, where e is the indicator of the amplitude of the oscillation, $\mathrm{s}$ is the indicator vibration frequency.

Secondly, since the cooperation of individuals always has a downside - the specialization of their activities, the demographic expansion of the primitive cooperative genus meant the deepening of the specialization of individuals, and this, in turn, allowed them in what -that moment to use for a more successful fulfillment of certain roles in the cooperation of external objects as tools of labor. This significant event of technogenesis came only after many millennia after sociogenesis. It is at the stage of technogenesis that the first external technological reaction of society takes place in the form of a tool transformation of the natural environment. Thirdly, the initial diachrony of socio-technological genesis persists throughout the subsequent development of the economy and is expressed in the alternation of significant historical technologies and sociologies of production. In fact, the entire history of society is a staged and cyclical process of restoring natural equilibrium through economic activity. Superwaves of adaptation spread from the primitive "ecumene" to the future developed highly organized "noosphere" [14].

Since anthropogenesis is associated with the emergence of a significant rarity of life benefits, the economy is a system of survival, and then the development of society, while economic theory solves the problem of overcoming this rarity, ensuring the growth of human well-being. And, fourthly, since from the point of view of the natural-social continuum, the emergence of people occurred at a certain level of their natural herd cooperation, the initial phase of the trajectory of the development of society somewhat goes beyond the frame of reference. The corresponding equation for the growth of civilization $\mathrm{S}=\mathrm{f}(\mathrm{P})$ in the third approximation of the model will already look like this: $\mathrm{S}=\mathrm{P}+\varepsilon \sin (\mathrm{k} \mathrm{s})$, where $\mathrm{k}$ under the sine sign is the proportionality coefficient, characterizing the initial phase of the megacycle. The horizontal sections of the model, lying along the ascending abscissa "P", correspond to the historical sequence of significant production technologies - manual, agricultural, commodity, machine, information and environmental, and the sections characterizing the advance along the ordinate " $\mathrm{S}$ ", represent, respectively, the tribal, communal, estate, constitutional, monopoly and global sociology of production.

The change in technologies and sociologies of social production in its history occurs in such a way that each of them is not destroyed, but in a transformed form is included in the economic mechanism of a more developed society, that is, there is a process of "removing" the simple from the complex as cyclic development of the initial syncretic state of society. Transitions to higher levels of technology and sociology of production also mean the achievement of higher levels of production efficiency.

\section{On the New Formational Division of the Evolution of Public Production}

Specific historical forms of economic management represent a unity of significant technologies and sociologies of production. In the global wave process, one can distinguish "Preformation", "Dformation", "Mesoformation", "B formation" and "Conformation", indicated in Figure 1 circles covering specific pairs of technologysociology. Each socio-economic formation is institutionally determined, has its own distinctive sociology of production, which formalizes its basic technology, but this sociology itself produces a new technology. Thus, all six historical significant technologies turn out to be connecting links of formations and are located in transition zones (in Figure 1, these zones are located at the overlap of adjacent circles - "formations"). "Preformation" means the first historical cycle of production, the cycle of its formation, in which the asymmetry of anthropogenesis is manifested and the whole "program" of the further development of society lies (the phenomenon of preformism, the most studied in the biology of the development of a living being). "Preformation" includes two production technologies - manual and agrarian - and two sociologies - generic and community [15].

"Dformation" means the duality of the second stage of society, its formation on the basis of extensive and intensive agricultural technologies implemented in history at the same time by different countries (see in Figure 1 the first bifurcation, that is, the branching of the trajectory of society's development). For example, Ancient Rome as an empire developed through territorial expansion and an increase in production, mainly through the seizure of land and 
the conversion of the population into slavery, while neighboring tribes could develop only intensively. Such efficient agriculture and subsistence farming is established in the "Dformation" everywhere and institutionalized in the form of "estate sociology". "Dformation" includes "slavery", "feudalism" and the so-called "Asian mode of production" - the beginning of agrotechnology in Mesopotamia (Sumerians), Egypt of the 4th millennium, Aegead (Western Asia Minor, the valleys of the Indus, Yellow River 2 millennium BC) and other regional modifications of early slave-owning society, since subsistence farming is characteristic of all twenty centuries of history covered by this cycle. The end of the Roman political empire was the beginning of the Christian-Catholic church empire, for the weakening of the state required the strengthening of the church in order to continue the development of the natural economy. "Dformation" seems to be one, absorbing the Greco-Latin and medieval world.

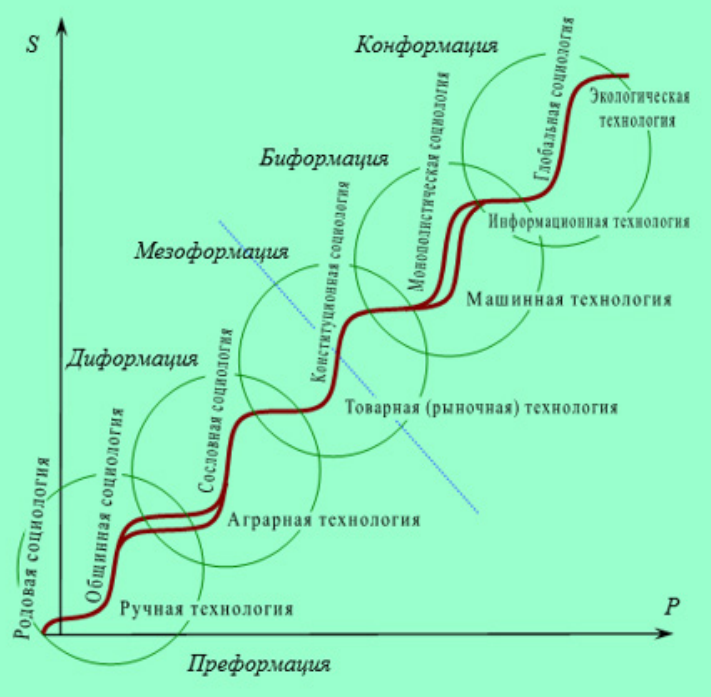

Figure 1.

"Mesoformation" represents the early simple market economy and occupies an intermediate, middle position in history. It is in the "Mesoformation" that civil society is formed as a social basis for the further progress of civilization. By its "commodity technology" we mean the process of public production that continues outside of individual specialized farms that do not create the final product or the entire set of necessary goods and therefore turn out to be interconnected by exchange market relations. The emergence of commodity exchange technology and the formation of a "commercial society" in history took place much earlier than it is commonly believed, from about the end of the XIII century. The name "constitutional sociology" refers to the system of market economy institutions that ensure individualism, individual and private property rights, freedom of entrepreneurship and competition. At the heart of this system of institutions were the relations that developed on the "Protestant ethics" of the reformation, which liberated people from church prohibitions on the "monetary technology of interest" and proclaimed the values of hard work, rationality and thrift [16].

Since the cyclical development is a stable repetition of the same phases, the primary cooperation of individuals (individuals), conditioned and caused by nature itself, by virtue of the shown action of the dialectical law of negation of negation is repeated in the market pre-industrial era and takes the form simple cooperation from the time of Smith. So cooperation has its "birth" and subsequent "rebirth". The secondary wave of public cooperation of already legal entities (enterprises and organizations) is already based not on a natural, but on a more solid, own, social basis - a civil society of private specialized commodity producers, consumers, interconnected by regular and general market exchange. We know that in market conditions, each employee does not have a whole complex of abilities for any type of labor, he does not have a completely universal workforce due to qualitative differentiation, the division of aggregate labor activity into more or less independent, isolated izvodstvennye actions. The deepening of the social division of labor is a progressive economic process, since the specialization of labor is the concentration of the individual's activity on the production of any particular type of material or spiritual wealth contributes to an increase in the effectiveness of labor, its productivity due to the saving of time in the manufacture of each thing or in the performance of any other work.

Therefore, the process of division of labor expresses the level of development of the productive forces of society: "The development of the productive force ultimately always comes down ... to the division of labor within society" [Marx, vol. 25, part I, p. 93]. Smith in The Wealth of Nations pointed to the division of social labor as a factor in increasing social wealth in the manufacturing period of the development of the capitalist market. As in primitive times, the new development of cooperation caused a radical change in production technology - it became machine. Its essence lies in the use of tools not by objects, but by the forces of nature, which sharply increases the efficiency of the economy. Knowledge of the mechanism of the emergence of the cyclical development of the economy allows not only to clarify the subsequent analogous, repetitive processes, but also to make a long-term forecast of socio-economic changes [17].

But, firstly, if Smith considered the division of labor a purely positive phenomenon, contributing to the growth of his productivity, then Marx showed the negative side of the division of labor - its alienation. We have shown that "alienation" is "alienation of people" as a form of development of their primordial cooperation, cooperation, and "labor" is an objectified labor, a commodity. Both negative manifestations of "human life activity" are characterized by the concept of "human implementation", which encompasses a number of formations. And, secondly, if Smith considered the market society to be natural, just and eternal, then according to Marx it is unnatural, unjust and immortal. 
The concept of "Biformation" means a bifurcated formation, which is formed on the basis of machine technology. The corporate monopolistic sociology in the West, which has formalized and consolidated sectoral control by the largest producers for the last 150 years, is supplemented in Bioformation with a centralist monopolistic sociology of countries with planned economies (see the second vertical bifurcation in the historical cycle in Figure 1). In this regard, Aron wrote: "I do not ask myself whether there is a contradiction between socialism and capitalism, I consider capitalism and socialism as two varieties of the same industrial society" [2]. And one can agree with this characteristic, adding only that, despite the differences in the institutional design of sectoral and national economic monopoly, both of these varieties can be designated by the concept "Social economy". The structure of "Biformation" is such that it contains not only a single initial technology for the market and planned economies, but also a common path for them to further develop production along the line of its informatization. The transformation of scientific information into the main means of labor and cooperation determines the "removal" of the laws of value and commodity-money relations in general in the global information network, since the exchange of information, unlike ordinary commodity exchange, does not lead to the alienation of this universal good. We can say that of the available resources, information is the only inexhaustible, non-diminishing resource [Steward] [18].

The fifth, largely not yet manifested, but the predicted cycle of development of social production falls on the phase of completion of the adaptation of human civilization to the surrounding nature due to the global deployment of information and then environmental technologies. "Environmental technology" we call the mass distribution of nature-saving and waste-free industries that provide a high quality of the environment for people, and the term "Global sociology", or "mega-sociology", characterizes the unified, highly mobile and rapidly restructuring institutions of the world community, which, however, correspond to the decentralized and demonopolized economies of the world adapted to each other.

There are many names for the new formation in the literature. In addition to Marx's "communism", it contains other names for the future society, given by economists and sociologists of different directions and countries: "superindustrial" by the American philosopher Alvin Toffler (1928-2016) [Toffler], "postindustrial general pstvo "American sociologist Daniel Bell (1919-2011) [Bell]," advanced industrial "German philosopher Herbert Marcuse (1898-1979) [Marcuse]," new industrial "American economist John Galbraith (1908-2006) (Galbraith), "Post-bourgeois" by the American historian George Licht -heim (1912-1973) [Lichteim], "post-capitalist" by the German philosopher Ralph Dahrendorf (1929-2009), "post-economic" by the Russian economist Vladislav Inozemtsev (b. 1968) [Inozemtsev], "post-civilizo bathroom "by the American economist Kenneth Boulding (1910-1993) [Boulding], the" active "American sociologist Emitai Etzioni (b. 1929) [Etzioni], the" technotronic "American politician Zbigniew Brzezinski (19282017) [Brzezinsky]," informational "by the Japanese anthropologist Tadao Umesao (1920-2010) and extensively presented by his compatriot, the philosopher Yoneji Masuda 91905-1995) [Masuda] [19].

We consider the names with the prefix "post-" and including "post-industrial society" to be inappropriate due to their vagueness, the name "information society" is the most adequate to the object under study, but it is more suitable for characterizing not the society itself, and the technology used in the economy. Taking into account the unification in the names of the formations we use, as well as the above-mentioned natural and social adaptive essence of the fifth formation, we call it "Conformation". The technological dichotomy of antiquity and the sociological dichotomy of the 20th century turn out to be interconnected. Countries that have gone through a slave-owning civilization in their development, have created a mechanism of compulsion to work, institutions of public power and democratic traditions, then, in a monopolized industrial economy, they skip the stage of a state-centralist system of planned economic management. On the contrary, countries and regions that have not gone through slavery subsequently gravitate towards the so-called "socialism" and, under certain other circumstances, inevitably develop in this totalitarian form of industrial society. So, contrary to Marx's theory, there is no need for a transition to an economy of state monopoly for all countries. At the same time, and such transitions can be considered natural, and not just "experiments of the leaders" or the manifestation of other subjective factors of history.

The presented historical forms of economy reflect the symmetry of the development of the contradiction of man, associated, on the one hand, with the symmetry of the laws of dialectics themselves, and, on the other hand, with the cyclical personality, repetition inherent in the natural and social continuum. Objective phenomena of symmetry allow, when modeling history, not only to more accurately characterize the times for which there is no sufficient and reliable information, but also to give an accurate long-term forecast of the development of society, technologies and sociologies of production. Moreover, the deeper the researcher "penetrates" into the past, the more accurate and broader the forecast of the development of symmetric phenomena and processes is. We can point to three types of symmetry in our model: rotation, shear and specular. The symmetry of rotation refers to the proportional arrangement of the waves of history in relation to the general axial, mainstream of the development of the world civilization in the coordinates "P - S". Shear symmetry, or overlapping, is found when the trajectory of the model is divided in half along the perpendicular line passing through the "constitutional sociology" of "Mesoformations" in Figure 1 when combining the formed "halves" of history.

At the same time, one can point to a lot of similar, similar processes and phenomena observed in pre-commodity and post- 
commodity societies. So, the predicted ecological adaptation of the global civilization repeats the ecological anthropogenesis of primitiveness, the primary cooperation of proto-people corresponds to simple cooperation in the market economy of "Mesoformation", the duality of "Difformation" is symmetric to the duality of it turns out that there is a possible absence of slavery and "socialism" in the development of society, as well as the presence of a powerful social pyramid in "Dformation" and "Biformation", etc. Mirror symmetry of history is associated with the opposition of many social phenomena: the isolation of natural economies and the socialization of market economies; the techno-logical duality of "Dformation" and the sociological duality of "B-formation"; sacralization of society - the spread of a religious cult in life in the first half of history - and subsequent secularization - gradual liberation from religious worship and church influence; the predominance of centro-impetuous (afferent) ties under feudalism and centrifugal (efferent) ties under "socialism", etc [20].

\section{The Essence of the Current Crisis of the Industrial Economy}

The industrialization of sectors of the economy, which sharply increases the size of capital and rapidly changes their competitiveness, makes the inter-sectoral flow of capital more intensive. As a result, competitive justice is established in society obtaining the same profit $(\mathrm{M})$ on capital $(\mathrm{K})$, in whatever industry it is represented. For simplicity, let's first imagine a market economy consisting of two branches: industry and agriculture. Let us also assume that the economy has a trade, payments and migration external balance, and the profitability of industry (Gpr) is slightly higher than the profitability of agriculture (Gsx). Under these rather realistic conditions, an overheated economy in one part of the economy will exhibit the phenomena of multiple intersectoral overflow of capital, overproduction of industrial and underproduction of agricultural products, and vice versa, as well as changes in the ratio of profitability of industries. The inevitable diffusion of capital transforms the locally "overheated" economy into an equilibrium intersectoral complex, which, in addition to the "agroindustry", will include construction, transport, trade, banking and other industries. After the completion of the oscillatory process of redistribution of investments, a situation of equal and average profitability of capital (G) will be achieved, that is, profitability at the level of the bank interest rate (Gb) of all sectors of the economy $(\mathrm{Gpr}=\mathrm{Gwith}=\mathrm{Gb}=\mathrm{G})$.

With such an equilibrium, the prices of individual goods (Xi) become dependent not only on the consumption of their production (Bi) and the profits earned (Mi), but also on the profitability of the economy as a whole and the amount of capital used (Ki), and the formula for the sectoral price $\mathrm{Xi}=\mathrm{Bi}+\mathrm{Mi}$ takes the form: $\mathrm{Xi}=\mathrm{Bi}+\mathrm{G}$. Ki. At the macro level, the formula looks exactly the same, the value of the nominal aggregate product $(\mathrm{Q})$, that is, its "production price" according to Marx will be equal to: $\mathrm{Q}=\mathrm{B}+\mathrm{G} \cdot \mathrm{K}$. Equal profitability of the spheres of capital investment testifies to the completion of the process of formation of a harmoniously developed national economy, the technological basis of which is the aggregate industrial capital closely intertwined in sectors. But the industrialization of market production led to a general downward trend in the average profitability of production ( Gav, Gav = M / $(C+V)$ ). The essence of the trend is that, despite the aspiration of private business to increase the profitability of business through the mechanization of production, at the macro level, a gradual monotonic decrease was observed. This, at first glance, a paradoxical phenomenon reflected the internal crisis of "Mesoformation" [21].

If we divide the numerator and denominator of the fraction by wages $\mathrm{V}$ in the indicator of the profitability of production (by the expenditure of "variable capital", in the terminology of Marx) and discard the resulting unit, then we find that profitability is proportional to the level of sociology of production and is inversely proportional to the level of production technology: Gav $=(\mathrm{M} / \mathrm{V})$ / $(\mathrm{C} / \mathrm{V})+1$, Gav $\sim \mathrm{S} / \mathrm{P}$. Since the real economy does not develop synchronously, cyclically, and at this stage machine technology was growing, and classical market sociology was already quite stable, the average profitability (G) of industrial production by the middle of the $19^{\text {th }}$ century in the form of the S / P ratio turned out to be minimal (Gav (min), see Figure 2a), hich meant the onset of the systemic crisis of "Mesoformation". The market economy was able to acquire a "second wind" in its further existence only with the transition from classical perfect competition to imperfect, monopolistic competition, which required a new institutional restructuring and, thus, an increase in the level of development of the sociology of production to "monopolistic sociology" ... The 150-year-old modern strip of development of the corresponding "Biformation" and represents the monopolization of first trade, and then the sphere of production national economies.

Having industrial technology as determinants, and the implementation mechanism for corporatization of capital, that is, duplication of physical capital with financial capital (in the form of securities - stocks and bonds) and splitting the latter into parts of an arbitrary denomination, monopoly provided corporate control of industry markets and the possibility due to the price dictate of obtaining superprofits. And this super-profit was necessary not so much as additional income for entrepreneurs and capital owners, but for reproduction in competitive conditions of industrial capital itself and society as a whole. The historical downward trend in profitability was replaced by a countertrend of its growth, the legitimate nature of which was first shown by the Italian economist Pierro Sraffa (1898-1983) (Laws of Profitability in Competition, 1926), and then by the Americans Paul Sweezy (1910-2007) and Paul Baran (1910-1964) (Monopoly Capital: An Essay on American Economic and Social Order, 1966).

The classical method of "internal" growth of enterprises by converting part of the profit into additional capital $(\Delta K)$, that is, by concentration of capital (Figure 2b), in the conditions of the industrial economy is insufficient and when establishing 
"Monopolistic sociology" is complemented by the process of centralization of capital, which made it possible to quickly increase the size of the corporation due to its "external" growth, that is, the absorption of small and medium-sized firms by large ones (Figure 2c). However, with the formation of the corporate economy and the harmonization of sociology and production technology, a fundamental disproportion inevitably arises in the factor structure of the rapidly growing aggregate product (Figure 3). Over a century of industrialization, from the mid-18th to the mid- $19^{\text {th }}$ centuries, the share of costs for raw materials $C$, as well as the excess profits $M$ in $\mathrm{Q}$, increased exaggeratedly. Affected not only the deployment of machine technology, but also the redistribution of income in favor of capital, part of the absolutely growing incomes of workers turned into monopolistic excess profits of corporations. Wages became inadequate to labor productivity and technological achievements of society, turned out to be incomplete and not sufficient for the expanded reproduction of the labor force of a large mass of hired labor [22].

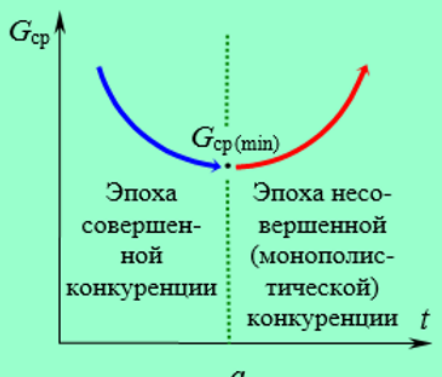

$a$

Figure 2.
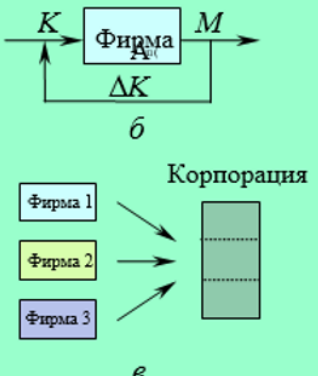

b
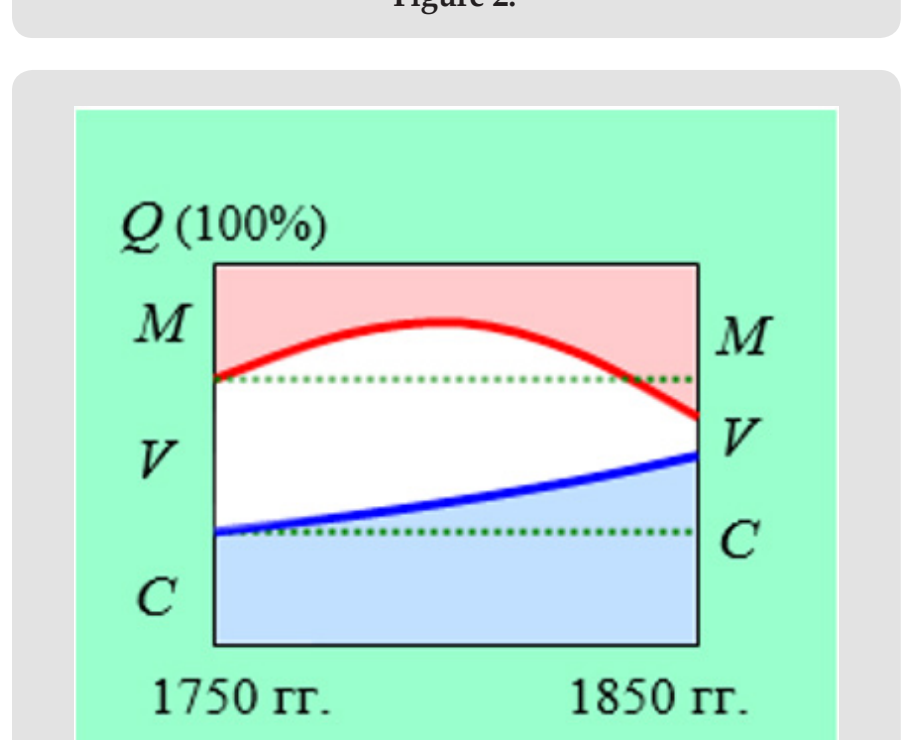

Figure 3.

Thus, by the middle of the $19^{\text {th }}$ century in the leading industrialized countries, such a production capacity of national economies was created, which, on the one hand, did not correspond to the narrow opportunities for selling products due to the low effective demand of the population, and, on the other hand, - shaft of additional sources of various raw materials. The accumulated industrial potential began to look for new resources and places of sale of goods in the world periphery, the process of intensive internationalization of capital began. Relatively surplus national capital rushed abroad on a large scale and successfully consolidated itself in the economies of countries with cheap labor and natural resources necessary for industry. Since it was about interstate relations, not only economic methods of competition were used, but also diplomacy, political pressure, knowingly enslaving lending, concessions, bribery of the comprador bourgeoisie and direct military expansion.

The aggregate overaccumulated capital in the form of monetary loans and industrial investments was initially exported to underdeveloped countries, many of which turned into colonies and semi-colonies, and after World War II, in the conditions of the "parade of sovereignty" of these countries and the absence in them modern market infrastructure was repatriated to the regions of the West. The global migration of capital, which at first ensured a further increase in its profitability, as the levels of socio-economic development of parts of the world economy approached, in the context of the transition to the market of former socialist countries and the advancement of the so-called "newly industrialized countries" of Asia and South America, led to the general trend of falling profitability again. The repeated decrease in the profitability of market production indicates that this basic indicator of the business activity of capital changes cyclically in the process of historical development. This is a sign of not only an increase in the homogeneity of the world community, but also the beginning of its transition to post-industrial, information technology. But, if the historical dynamics of profitability in the market is a cycle, what is its trend and what are its origins and prospects?

\section{Criterion of Production in the Digital Economy}

Formation analysis of society shows that the trend of the cycle of profitability, as well as the entire history of social production, is the absolute constant of nature in its broad sense, that is, including society, the so-called "golden proportion" of nature, which operates in all its specific formations of physical, chemical, biological, social origin and establishes equilibrium and harmony in them. Most simply, the "golden ratio" is determined by geometric division of an ordinary line segment into two parts. If its length is designated as one, its smaller part - for $\mathrm{x}$, and the larger - for 1 - $\mathrm{x}$, then the harmony of the segment will be observed when it is cut in proportion: the ratio of the small part to the large part is equal to the ratio of the latter to the entire segment: $x /(1-x)=(1-x) / 1$. From here we find $\mathrm{x}$ in the form of a quadratic equation $\mathrm{x}=1-2 \mathrm{x}+\mathrm{x}^{2}$, the solution of which gives us the numerical value of the "golden ratio": $\mathrm{x}=$ 0.382. We designate this universal constant of harmony as GГ. With regard to society, GG characterizes the harmony of profitability of 
production (GP) and, in general, net profitability for any method of production: $\mathrm{G}==(\mathrm{A}-\mathrm{B}) / \mathrm{B}$, where $\mathrm{A}$ and $\mathrm{B}$ are specific indicators of results and costs, respectively.

In Figure 4 shows the general historical and prospective dynamics of the indicator G. The trajectory has a wave damping character and reflects the gradual, post-step compensation of the ecological catastrophe - a sharp cooling in the next "ice age", which led to the appearance of the human community in the Earth's biota state. His production activity comes in the long term to stabilization of the disturbed "golden ratio" with the final formation of an integral system "nature - society". trajectory cycles characterize the historical sequence of economic criteria - the profitability of the agricultural, the profitability of the industrial, the "salary" of the information and "environmental friendliness" of the global society. The design of these four criteria is the same and is such that all three elements of the value of the produced product, that is, $\mathrm{C}, \mathrm{V}$ and $\mathrm{M}$, become in turn the numerator of the total indicator of the profitability of production $\mathrm{G}$ as the residual target result, that is, $\mathrm{C}, \mathrm{V}$ and $\mathrm{M}$, and they are also included in the denominator of the fraction in as a cost element.

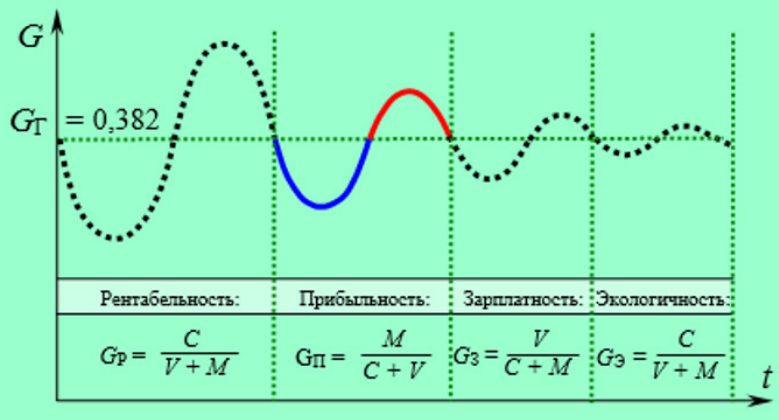

Figure 4.

So, since in primitive times the "golden proportion" began to decline, then in the criterion of profitability of management (GP) introduced in a practical way, a natural rent $\mathrm{C}(\mathrm{GP}=\mathrm{C} /(\mathrm{V}++\mathrm{M}))$ appeared, which allowed people not only successfully overcome the adverse consequences of environmental disaster, but also improve their well-being. The growth of $\mathrm{C}$ also allowed the reproduction of land as the main factor of production and the development of agriculture. In the conditions of an industrial economy, the first historical criterion of production turned out to be ineffective and was replaced by profitability (GP, GP $=\mathrm{M} /(\mathrm{C}+\mathrm{V})$ ). And in this construction the priority of profit was dictated by the task of growth and development of capital, that is, by the very machine technology. The dynamics of GP, like the dynamics of GP, was cyclical (in Figure 4 , its phases considered above fall on the second cycle of the graph), but the industrial cycle in terms of amplitude turned out to be less than the agrarian cycle and thus significantly brought society closer to indicator of absolute harmony GG.
With the completion of the formation of industrial capital and the transition to a social market economy, the salary $\mathrm{V}$ becomes the residual income, and the profit $\mathrm{M}$ should be attributed to costs. The corresponding criterion of "wages" of production (G3, G3 = V / $(\mathrm{C}+\mathrm{M})$ ) is not the fruit of pure theory, it is predetermined by the entire course of the historical development of social production and is adequate to modern information technology, the task of development "Human capital", education and innovation economy. It is important to note that the new criterion is designed to achieve not only economic, but also social goals, since for the first time in history it is directly related to the satisfaction of the complex of needs of the person himself. In fact, we are talking about "real socialism", and not about the once existing "formal" socialism, where a person was still an instrument of centralized industrialization of economies. The economic calculation that was used in the planned economy, basically did not differ from the usual market commercial calculation. Here and there profit was at the forefront. It is she who is primarily interested in the owner of capital goods, be it a private entrepreneur or a centralist state apparatus. Focusing on the wages of production should sharply increase its overall efficiency and directly the welfare of workers.

The objective need for a complete transition to the criterion of wages in modern conditions is indicated by the global decline in the profitability of production (see its second downward phase in Figure 4). and in the modern market it already exists in the form of a deformation of the criterion of profitability of production by expanding the so-called system of participation in the property and profits of corporations. Salary as a criterion and universal tool for solving social problems does not depend on modern forms of ownership, which, in the conditions of information technology, is subject to dissipation (dispersal) in society. Therefore, the new criterion. It was also generated during the crisis of the planned economy in our country by the very economic practice of the socalled "brigade contract". The experience of its actual application in the 70s and 80s in construction by Nikolai Travkin (b. 1946) (now a politician), healthcare surgeon Svyatoslav Fedorov (1927-2000) and other industries showed an explosive positive effect, but then it was subjected to harsh attacks from the bureaucratic system and was curtailed in the course of further profitable-market-night transformations in the country. It seems that the introduction of the salary criterion even under conditions of preservation state-owned resources, but their free lease, would bring much more benefit to society than the long-drawn-out transition to the classical market through the privatization of state property.

The so-called financial and economic crisis, in which the world community has been living since 2008, is associated with the transition to a new criterion of production. Experts, politicians and many ordinary people refer to it as a common cyclical phenomenon, which, as we found out above, is regularly observed in the market economy. Some experts note the seriousness of the situation and compare the current crisis with the Great Depression,which swept 
the Western world in the 20-30s. Despite the fact that a lot of time has passed since the appearance of negative processes in the financial sector, and then in the real sectors of the economy, summits, conferences were held, and even various systems of measures were announced to overcome the crisis and prevent its recurrence, surprising answers to questions about the causes, essence, duration of the crisis, as well as the nature of the functioning of the world economy in the post-crisis perspective did not appear. There is a widespread version about the mistakes made by the financiers, consisting in the so-called "refinancing" and artificial "overheating" of the stock markets.

However, the explanation of the crisis by purely market, opportunistic, reasons cannot be considered sufficient. It is known that the financial sphere primarily reacts to ongoing social and political events, but it also quickly and stabilizes with appropriate measures of business entities and the state. This time, after the financial bubbles began to burst, the credit system has not stabilized, which indicates the presence of a stable overaccumulation of capital in relation to the declining growth rates of the production apparatus and the level of its profitability in industrialized countries. And this phenomenon turns out to be completely different from what happened during the Great Depression of the market: then, as you know, the problem was the insufficient investment activity of the business.

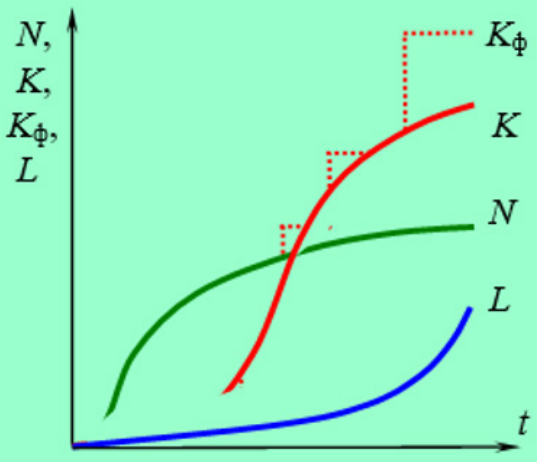

Figure 5.

Each of the three indicated historical criteria ensured the predominant growth and development of the corresponding factor of production, although it made the economy homogeneous, but at the same time introduced resource disharmony into it, which is eliminated only with the complete attenuation of the nonequilibrium process of interformational transitions. In Figure 5 shows the proportions of the historical joint dynamics of agrarian $(\mathrm{N})$, industrial $(\mathrm{K})$ and informational $(\mathrm{L})$ production factors. The growth line of industrial capital goods is associated with the dynamics (dashed line) of financial capital (Kf), which, although it has its own market, is constantly adjusting to the volume of capital goods. In the conditions of modern stabilization of the world production apparatus, there is a separation from it that grows by inertia, that is, in the mode of not ordinary investment activity, but a monetary "pyramid", financial "fictitious" capital. The restoration of normal operation of the financial sector will occur if it begins to invest in the growth of not the industry, but the service sector of "human capital", which is still relatively undeveloped.

No rost investitsionnogo potoka $v$ sfery obrazovaniya $i$ formirovaniya sovremennoy rabochey sily $v$ usloviyakh sokhraneniya chastnoy sobstvennosti i rynka, trebuyet primeneniya kriteriya zarplatnosti, kotoryy pozvolyayet sozdat' moshchnyy fond dlya postroyeniya deystvitel'nogo sotsializma. But the growth of investment flow in education and the formation of a modern workforce in conditions of preservation of private property and the market requires the use of the criterion of salaries, which allows you to create a powerful fund for building real socialism. V dolgosrochnoy istoricheskoy perspektive posle resheniya s pomoshch'yu kriteriya zarplatnosti proiz-vodstva osnovnykh sotsial'nykh problem sovremennosti $i \quad v$ usloviyakh neobkhodimosti preodoleniya neizbezhnykh problem prirodopol'zovaniya obshchestvu pridetsya vvodit' $v$ deystviye yeshche odin, chetvertyy, kriteriy proizvod-stva kriteriy yego ekologichnosti $(\mathrm{GE}, \mathrm{GE}=\mathrm{C} /(\mathrm{V}+\mathrm{M}))$, kotoryy vneshne, po svoyey konstruktsii, sovpadet s istoricheski iskhodnym kriteriyem rentabel'nosti zemli, no na novom urovne ekonomicheskoy kul'tury obshche.

In the long-term historical perspective, after solving the main social problems of our time using the criterion of production wages and in the conditions of the need to overcome the inevitable problems of environmental management, society will have to introduce another, fourth, criterion of production - the criterion of its environmental friendliness (GE, GE $=\mathrm{C} /(\mathrm{V}+\mathrm{M})$ ), which outwardly, in its construction, coincides with the historically initial criterion of land profitability, but at a new level of economic culture of the general society will allow the residual formation of the "income of nature" $\mathrm{C}$ and thereby finally stabilize the indicator of the general efficiency of human civilization G, equating it to the "golden ratio" GG.

\section{Conclusions}

The digital economy should correspond not only to information technology, but also to global sociology, which is a universal system of social institutions that formalizes the operation of the salary criterion, which does not depend on the form of ownership of material factors of production, for priority development is human capital transforms natural rent and profits into social costs. Accordingly, to this fundamental conclusion, discussions about planned economic management, the height of which was in the 20-30s of the last century, that is, the times when there were still two economic systems in the world, are again gaining significance market and planned - and there were not only ideological, but also scientific disputes between their supporters and opponents. The controversy was widespread, and in the Western economy too. 
From the past, Mises's "theorem of the impossibility of socialism" (Socialism: economic and sociological analysis, 1922), which arose in the conditions of the real functioning of centralist systems, and the idea of the "intellectual delusion of socialists" Hayek (Fatal charm. Errors of socialism, 1988), which can be reduced to three postulates, informational properties: 1) any compulsory organization of society, including a planned economy, does not provide reliable information necessary for coordinating the activities of manufacturers - conducting business accounting; 2) the central planning body cannot technically collect, process and use the entire array of socio-economic information; 3) planning information is static in nature, while the economy is a dynamic system.

Some Western economists, observing the initial successes of centrally organized economies, tried to challenge the stated postulates of the "Austrians" and oppose them with their theoretical arguments in defense of socialism. These were, first of all, the English economists Henry Dickinson (1899-1969) (Formation of prices in the socialist community, 1933; The Economics of Socialism, 1939), Frank Durbin (1906-1948) (Economic calculation in a planned economy, 1936), concentrating attention to the problems of collecting the necessary economic information for the plan, and the Polish economist Oskar Lange (1904-1965) (The road to a socialist planned economy, together with M. Breit, 1934; On the economic theory of socialism, 1936, 1937), which introduced into the analysis the so-called "parametric prices", similar to those that are allowed by the counterparties of the markets as "price recipients" in the conditions of their perfect competition. In economic theory, a section even appeared called "planometrics", and Lange, obsessed with the desire to implement his idea of calculating market prices without a market, after a long successful creative stay in England and the USA, being strongly influenced by Western ideas economists, Austrian Joseph Schumpeter (18831950), Americans Paul Sweezy (1910-2007) and Vasily Leontiev (1906-2001), returned to his homeland, to socialist Poland, and in 1955 he headed the State Economic Council there with the aim of replacing the model of the virtual market "auctioneer" operating in the model of the Swiss economist Leon Walras (1834-1910) with a real directive subject.

However, attempts to theoretically substantiate centralized planning, undertaken by the named and other economists, representatives of the System for the Optimal Functioning of the Economy (SOFE) in the USSR and similar scientific schools in other countries, were unsuccessful. The crisis events in the socialist countries at the end of the 20th century, which led to the restoration of markets in them, allowed many economists, both denying the possibility of economic calculation, and supporting the global planning experiment of the 20th century, or loyally treating it, talk about the final fiasco of socialism. So Huerta de Soto (Socialism, Economic Calculation and Entrepreneurial Function, 1992) without sufficient grounds and even mention of the studies of the Italian economist, neo-Ricardian Piero Sraffa (1898-1983) (Production of goods through goods, 1960 ), who substantiated the reality of the macroeconomic "production price" of Marx $(\mathrm{Q}=$ $B+G \cdot K)$, called the creation of market socialism "square of the circle" [Huerta de Soto, p. 412], that is, a fundamentally unsolvable problem. The American economist Robert Heilbroner (1919-2005) (Marxism: Pros and Cons, 1980) wrote: "Mises was right.

Socialism turned out to be the great tragedy of ... century" [Heilbroner, p. 1110-1111]. But, in our opinion, it is too early to close both theoretical and practical disputes about the plan and the market. Moreover, the issue of directive planning is becoming very relevant on a global scale. Vazhno ponyat', chto avstriyskaya shkola ne yavlyayetsya $v$ sovremennoy ekonomicheskoy teorii $v$ tselom i teo-rii sotsializma $v$ chastnosti, yedinstvennoy, chto raznyye kontsep $\neg$ tsii sotsializma sovershenno ne obyazatel'no dolzhny proveryat'sya predstavlennymi vyshe tremya postulatami Mizesa-Khayyeka o nevozmozhnosti khozyaystven-nogo rascheta. Ravnovesnaya rynochnaya i nerynochnaya ekonomicheskaya teoriya, otvergayemaya avstriyskoy shkoloy, mozhet na svoikh printsipakh razvivat' prezhniye i sozdavat' novyye kontseptsii «planometriki».

It is important to understand that the Austrian school is not the only one in modern economic theory in general and the theory of socialism in particular, that different concepts of socialism do not necessarily have to be verified by the above three postulates of Mises-Hayek about the impossibility of cost accounting. Equilibrium market and non-market economic theory, rejected by the Austrian school, can develop the old and create new concepts of "planometrics" on its own principles. Analysis and proposals for the development of the basic ideas of economic theory [23] show, in contrast to the postulates of "Austrian antisocialism", that: 1) the plan requires not primary comprehensive microeconomic information, but only one macroeconomic indicator ("national dividend", G), which optimally combines both extensive and extensive opportunities for the development of the economy; 2) this indicator expresses not the diversity of interests of the entire mass of economic entities, but, on the contrary, their monotonous and universal interests - employment and growth of well-being; 3) this indicator reflects not the statics, but the dynamics of the economy.

\section{How Can these New Theoretical Positions be used Constructively?}

Unfortunately, Lange, developing his model of cost accounting, only imitating market balances, believed that state producers of goods should, as in commercial accounting, maximize profits. Sraffa, going further in creativity Lange, also could not completely free himself from market concepts when creating a macromodel of the estimated "production price" and assumed equalization in all sectors of the profitability of capital. Both views, in our opinion, close the way of developing cost accounting. For a centralized plan, it is not the maximization and uniformity of the profitability of production that is needed, but the macroeconomic optimization 
of profitability according to the criteria of employment and innovation, with the subsequent differentiation of the indicator by industry. In a "country-a single firm", all of its production units can be the recipients of such "parametric prices", which include not only different costs based on input-output balances, but also different profits, in total equal to the value of the optimal national dividend. Such a system of business accounting does not contradict the market, does not displace it from the life of society, meets the criterion for the growth of human capital and can cover the entire complex of social relations.

The observance in the development of the market of the principle of classical political economy on non-interference of the state in private business (the laissez-faire principle), which supposedly guarantees the welfare of the whole society, in fact in different formations led and is leading to the distribution of created values in favor of individual factors of production. So, if profitability for a long historical time increased land wealth, and then profitability provided the outstripping growth of capital goods, then with the wages institute, conditions will be created for the free and full development of the employee. Therefore, the sectoral investment allocation of the national optimal dividend, in fact, turns it into an element of costs, and all kinds of savings in the production of goods are allowed, according to the residual principle, to be attributed to wages as a financial source of human development. When an economic reform was being prepared in the USSR at the beginning of the $90 \mathrm{~s}$, it was possible to radically change the nature of a state-controlled and centralized economy by the widespread introduction of a system of leasing enterprises and a new criterion of production, which is local and spontaneous, as we are shown above, has already been applied and gave excellent results.

However, then circumstances developed in such a way that the reform applied methods of "shock therapy", which doomed the country to dishonest privatization of state property, hyperinflation and its subsequent existence with a corrupt "pseudo-market". But such a stupid economic situation should serve as an incentive for the early introduction of institutional innovations in Russia. In this case, the "digitalization" of the economy is becoming very important.

\section{ISSN: 2574-1241}

DOI: 10.26717/BJSTR.2021.33.005384

Vladimir Sergeevich Grodsky. Biomed J Sci \& Tech Res

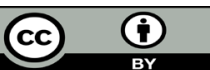

This work is licensed under Creative Commons Attribution 4.0 License

Submission Link: https://biomedres.us/submit-manuscript.php

\section{References}

1. Aron R (1993) Imaginary Marxism. - M: Progress.

2. Blaug M (1994) Economic thought in retrospect: Textbook. - M: Delo Ltd.

3. Grodsky VS (2012) Problems of Modern Economics: Textbook. - M: Economics.

4. Toffler A (1970) Future Shock. - N.Y.: Bantam Books.

5. Aron R (2000) Selected: Introduction to the philosophy of history. - SPb.

6. Grodsky VS (2016) Development of the basic ideas of economic theory. - M: INFRA-M.

7. Inozemtsev VL (1996) Essays on the history of the economic social formation. - M: Taurus Alpha, Vek.

8. Lenin VI (1958-1965) Complete Works. In 55 volumes - M: Politizdat.

9. K Marx, F Engels (1955-1982) Works. In 50 volumes - M: Politizdat, 1955-1982.

10. Samuelson PE (2002) Foundations of economic analysis. - SPb: School of Economics.

11. Huerta de Soto H (2007) Austrian School of Economics: Market and Entrepreneurial Creativity. - Chelyabinsk: Socium.

12. Ere J (2014) The birth of capitalism in the Middle Ages: money changers, usurers and large financiers. - SPb.

13. Bell D (1973) The Coming of Post-Industrial Society. A Venture of Social Forecasting. - N.Y.: Basic Books.

14. Boulding KE (1965) The Meaning of the Twentieth Century. - N.Y: Harper \& Row.

15. Brzezinsky Z (1970) Between Two Ages: America's Role in the Technotronic Era. - N.Y.: Viking Press.

16. Etzioni A (1968) The Active Society: A Theory of Societal and Political Processes. - N.Y.: Free Press.

17. Galbraith JK (1964) The New Industrial State. - Boston: Houghton Mifflin.

18. Heilbroner RL (1985) Analisis and Vision in the History of Modern Economic Thought. Journal of Economic Literature 28(3): 1097-1114.

19. Lichteim G (1961) Maxism: An Historical and Critical Study. - N.Y.: Harper Collins.

20. Marcuse H (1965) Tolerance: Freedom of Speech / A Criticue of Pure Tolerance. - Boston: Beacon Press.

21. Marx K (1867) Das Kapital. Kritik der Politischen Öekonomie. Hamburg, Verlag von Otto Meissner.

22. Masuda Y (1981) The Information Society as Post-Industrial Society. Wash.: Free Press.

23. Steward T (1997) Intellectual Capital. - L.

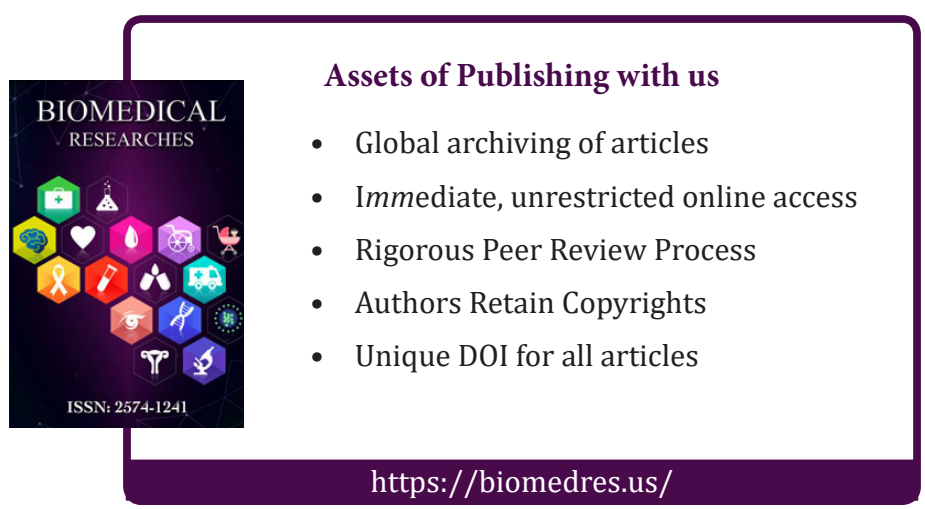

Copyright@ Vladimir Sergeevich Grodsky | Biomed J Sci \& Tech Res | BJSTR. MS.ID.005384. 